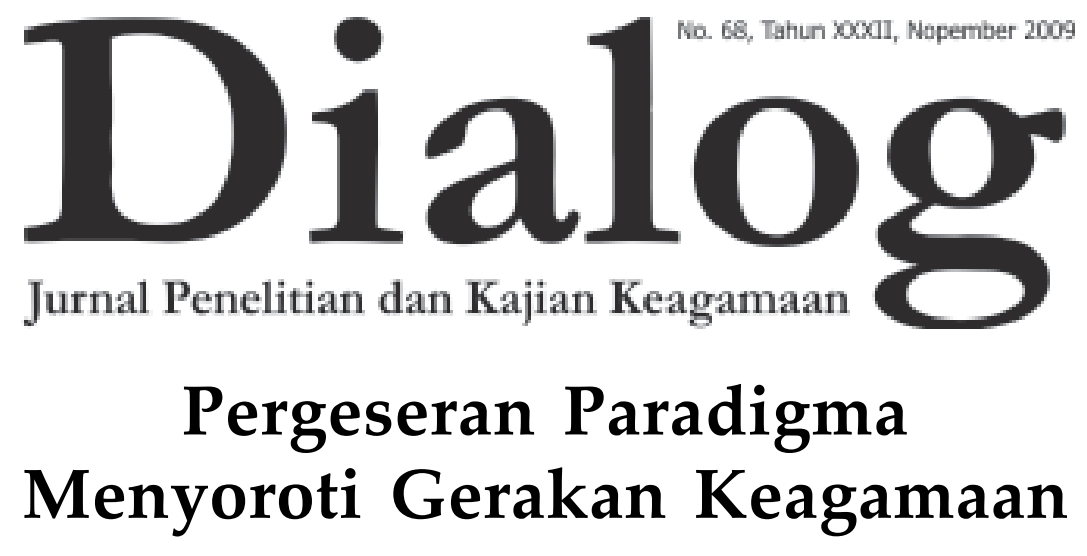




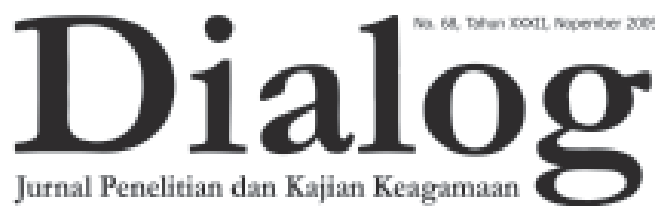

Pemi mpin Umum:

Prof. Dr. H. M. Atho Mudzhar, MA

Redaktur Ahli:

Prof. Dr. H. Nasaruddin Umar, MA

Prof. Dr. H. Komarudin Hidayat, MA

Pemimpin Redaksi / Penanggung J awab

Drs. H. Syamsuddin

Wakil Pemi mpin Redaksi

H. Fanani Suprianto, SH., MM

Sekretaris Redaksi

M. Rosyid Fauzi, S.Si.

Dewan Redaksı

Prof. Dr. H. Abdurrahman Mas'ud Drs. Amin Haedari

Prof. Dr. H. Maidir Harun

Drs. H. Mohammad Shohib, MA

Drs. H. Asmu'i, SH, MM

Chamdi Pamudji, SH., MM

Redaktur Eksekutif

M. Nasir, S.Th.I.

Redaktur Pelaksana

Moh. Rosyid Fauzi, S.Si

M. Nasir, S.Th.I

M. Adlin Sila, M.A

Abbas Jauhari, M.Ag

Administrasi

Drs. Dedy Curipno

Sutidjah

Desriyanti Nasution, S.IPI

Drs. H. Sahlani

Alamat Redaksi

Gedung Bayt Alquran Museum Istiqlal Komplek Taman Mini Indonesia Indah

Telp. (021) 87791444-87794982

Website:

www. balitbangdiklat.depag.go.id

Email:

info@depag.web.id

\section{Pergeseran Paradigma Menyoroti Gerakan Keagamaan}

Fenomena munculnya berbagai aliran keagamaan di Indonesia beberapa tahun terakhir menunjukan kecenderungan positif dalam kebebasan beragama. Namun sayangnya kebebasan menampilkan ekspresi keberagamaan tersebut kerapkali melampaui dari apa yang semestinya. Hal tersebut dapat kita lihat dengan munculnya gerakan keagamaan yang mengusung berbagai macam ajaran, ritual keagamaan yang aneh bahkan cenderung mengancam serta menodai kesucian aqidah, ibadah, ritual, dan pendirian mayoritas ummat yang sudah mapan. Sejak tahun 1989, setidaknya telah ada beberapa aliran keagamaan diberikan label haram oleh MUI (Majelis Ulama Indonesia), diantara aliran yang dianggap menyesatkan itu antara lain: Islam Jama'ah, Ahmadiyah, Ingkar Sunnah, Qur'an Suci, Sholat Dua Bahasa, Lia Eden dan al-Qiyadah al-Islamiyah.

Fenomena ini ditenggarai oleh sebagian pihak sebagai akibat dari kegagalan dakwah. Para da'i dianggap tidak mampu mentransformasikan nilainilai ajaran Islam secara kaffah 
(komprehensif) kepada ummat, dakwah selama ini sering bersifat eksklusif, menghakimi dan memprovokasi. Aktifitas dakwah hanya menampilkan Islam dari aspek langit atau 'ubudiyah (habluminallah) bukan aspek bumi dimana kehidupan sosial (habluminannas) bergulir, sehingga wajar berbagai permasalahan sosial yang dialami ummat tidak tersentuh. Fakta ini menyebabkan ummat mencari solusi lain atas permasalahan sosial yang mereka alami dengan cara "selingkuh" yaitu menganut sekte atau aliran baru dalam sebuah agama yang menawarkan solusi instan, namun cenderung "menyesatkan".

Para da'i, tokoh masyarakat, maupun para pemegang kebijakan ke depan harus mampu merubah paradigma yang selama ini salah dan telah mengkristal di kalangan ummat. Mereka diharapkan tidak berperan sebagai juru dakwah, juru vonis, juru putus, yang hanya menyampaikan pesan bil lisan di atas mimbar saja, tapi lebih dari itu, merek dituntut menjadi -meminjam istilah Clifford Geertz- cultural broker (makelar budaya), bahkan menjadi intermediary forces (kekuatan perantara) bagi permasalahan sosial ummat dalam istilah Hiroko Horikoshi.

Dalam kajian Jurnal Dialog Edisi ini mencoba mengulas tentang Pergeseran Paradigma Menyoroti Gerakan Keagamaan yang kerapkali menghadirkan tematema aktual di tengah-tengah masyarakat. Kajian Jurnal Dialog edisi ini diawali dengan tulisan Prof. Dr. H.M.
Atho Mudzhar tentang Instrumen Internasional dan Peraturan Perundangan Indonesia tentang Kebebasan dan Perlindungan Beragama. Dilanjutkan dengan tulisan Prof. Dr. Abdurrahman Mas'ud yang mengupas tentang Menyikapi Keberadaan Aliran Sempalan.

Sukris Sarmadi, Dosen STAIN Banjarmasin menghadirkan tulisan tentang Transformasi NU dalam Masyarakat Banjar Kini PerspektifPergeseran Gerakan Keagamaan di Kalimantan Selatan. Sedangkan M. Ulinnuha Khusnan, MA melalui tulisannya mencoba memotret Paradigma Keberagamaan Kaum Santri. Nurhasanah dosen UIN Jakarta menghadirkan tulisan tentang Politik Kebijakan Islamisasi Mahathir. Kajian jurnal dialog edisi ini kian lengkap dengan hadirnya tulisan Anwar Mujahidin, MA, tentang Science And Religion (Paradigma Al-Qur'an untuk IlmuIlmu Sosial Menurut Pemikiran Kuntowijoyo).

Di samping memuat artikel ilmiah, Jurnal Dialog edisi ini juga memuat laporan hasil penelitian oleh Ridwan Bustaman, tentang Analisis Wacana Kritis : Tayangan Kekerasan dalam Sinetron Bernuansa Keagamaan. Dan juga hasil penelitian saudara Basuki tentang Pesantren, Tasawufdan Hedonisme Kultural (Studi Kasus Aktualisasi Nilai-nilai Tasawuf dalam Hidup dan Kehidupan di Pondok Pesantren Modern Gontor). Serta hasil penelitian saudari Maryam tentang Interaksi Sosial Pelaku Konversi Agama Etnik Cina.

Kajian ini diakhiri dengan telaah 
buku yang mengulas buku karya Prof. Abdurrahman, 2009 yang berjudul Menebar Rahmat bagi Sekalian Alam. Semoga kajian yang dihadirkan Jurnal Dialog edisi ini memberikan manfaat yang berarti bagi para pembaca, khususnya dalam kajian Pergeseran Paradigma Menyoroti Gerakan Keagamaan. Selamat Membaca!

Redaksi

4 Dialog No. 68, Tahun XXXII, Nopember 2009 
TOPIK

M. Atho Mudzhar

Instrumen Internasional dan Peraturan Perundangan Indonesia tentang Kebebasan dan Perlindungan Beragama - -6

Abdurrahman Mas'ud

Menyikapi Keberadaan Aliran Sempalan --16

SUKRIS SARMADI

Transformasi NU dalam Masyarakat Banjar Kini Perspektif Pergeseran Gerakan Keagamaan di Kalimantan Selatan - 25

\section{Ulinnuha KhuSNAN}

Memotret Paradigma Keberagamaan Kaum Santri —41

\section{NuRHASANAH}

Politik Kebijakan Islamisasi Mahathir —65

\section{Anwar Mujahidin}

Science And Religion (Paradigma Al-Qur'An untuk Ilmu-Ilmu Sosial Menurut Pemikiran Kuntowijoyo) -78

\section{PENELITIAN}

\section{RidWAN Bustamam}

Analisis Wacana Kritis : Tayangan Kekerasan dalam Sinetron Bernuansa Keagamaan $\longrightarrow 97$

\section{BASUKI}

Pesantren, Tasawuf dan Hedonisme Kultural (Studi Kasus Aktualisasi Nilainilai Tasawuf dalam Hidup dan Kehidupan di Pondok Pesantren Modern Gontor) -112

MARYAM

Interaksi Sosial Pelaku Konversi Agama Etnik Cina --135

\section{BOOK REVIEW}

\section{Dewi $\mathbf{N}$}

Menebar Rahmat bagi Sekalian Alam —149 


\title{
Pesantren, Tasawuf dan Hedonisme Kultural (Studi Kasus Aktualisasi Nilai-nilai Tasawuf dalam Hidup dan Kehidupan di Pondok Pesantren Modern Gontor)
}

OLEH : BASUKI*)

\begin{abstract}
Islamic School has the basic essence that can not be separated from the characteristics of the pesantren institution that always stress the importance of moral Akhlaqul Karimah as a guideline life of everyday society. Therefore pesantren education system has always been and always aim to develop the personality Muhsin, not just Muslims. Muhsin personality mentioned is Sufism. This is where the intersection between Sufism and Islamic schools. The essence of Sufism is pengejawan charity, while the essence of boarding schools located in the personality development of Muhsin. In this third millinium century boarding schools are in the mainstream of life of the paradigmatic capitalism, and the condition of society that have become jungle hedonism. This brief article is the result of field research has revealed how the actualization of the values of Sufism in the modern pesantren Gontor the era of global education and cultural hedonism.
\end{abstract}

\section{Keywords:}

Pesantren, Mukmin, Muslim, Muhsin, Sufism, Cultural Hedonism

\section{Pendahuluan}

Pesantren dengan berbagai bentuknya mempunyai tujuan, baik tujuan umum maupun tujuan khusus. Tujuan khusus pendidikan pesantren yang dimaksud adalah mempersiapkan para santri untuk menjadi orang yang 'alim dalam ilmu agama yang diajarkan oleh kyai yang bersangkutan serta

*) Penulis adalah Dosen Tetap STAIN Ponorogo dan Dosen Luar Biasa ISID Pondok Moder Gontor. Makalah ini telah dipresentasikan oleh penulis sebagai 10 artikel hasil penelitian terbaik pada acara Annual Conference Program Pascasarjana IAIN/UIN se-Indonesia di IAIN Alaudin Makasar,Tanggal 2527 Nopember 2005 mengamalkannya dalam masyarakat. Sedangkan tujuan umum pesantren adalah membimbing anak didik menjadi manusia yang berkepribadian Islam yang sanggup dengan ilmu agamanya menjadi muballig Islam dalam masyarakat sekitar melalui ilmu dan amalnya. ${ }^{1}$ Disamping itu, secara umum setiap pesantren niscaya mendambakan dan ikut serta berupaya melahirkan generasi penerus (out put) yang selain memiliki keunggulan bersaing (compe-

\footnotetext{
${ }^{1}$ Djamaluddin \& Abdullah Aly, Kapita Selekta Pendidikan Islam, (Bandung: Pustaka Setia, 1998), 106
} 
titive advantage) untuk menjadi subyek dalam percaturan di dunia kerja juga memiliki kepribadian yang utuh (integrated personality) sehingga dapat memakmurkan dan memuliakan kehidupan material dan spiritual diri, keluarga dan masyarakatnya berdasarkan nilai-nilai Islam. ${ }^{2}$

Keberadaan pesantren baik salaf atau modern pada saat sekarang ini dihadapkan pada tantangan arus globalisasi, ${ }^{3}$ yang telah melanda di berbagai belahan dunia yang merupakan akibat dari pesatnya perkembangan teknologi komunikasi, informasi dan transformasi yang menjadikan bumi ini semacam desa global (global village), sehingga tak heran kalau antar negara-bangsa bisa saling memberi pengaruh. Dan kita sekarang telah memasuki abad ke-21, sebagaimana disebut banyak orang, abad ke-21 adalah millinimum baru yang kita belum tahu persis bagaimana sosoknya, akan dibawa kemana umat manusia. ${ }^{4}$

${ }^{2}$ Demikian makna eksplisit Al-Qur'an, surat alNisaa' ayat 9 yang artinya "Dan hendaklah takut orang-orang yang seandainya meninggalkan di belakang mereka anak-anak yang lemah, yang mereka khawatir terhadap (kesejahteraan) mereka. Oleh sebab itu hendaklah mereka bertaqwa kepada Allah SWT dan mengucapkan perkataan yang benar."

${ }^{3}$ Era Globalisasi dewasa ini dan di masa datang sedang dan akan mempengaruhi perkembangan sosial budaya masyarakat muslim Indonesia umumnya atau pendidikan Islam, termasuk Pesantren, khususnya. Argumen panjang tak perlu dikemukakan lagi, bahwa masyarakat muslim tidak bisa menghindarkan diri dari proses globalisasi tersebut, apalagi jika ingin survive dan berjaya di tengah perkembangan dunia yang kian kompetitif di masa kini dan abad ke-21. Lihat dalam Azyumardi Azra, Pendidikan Islam: Tradisi dan Modernisasi menuju Millinium baru, (Jakarta: Penerbit Kalimah, cet ke-3, 2001), 43.

${ }^{4}$ Dalam hal ini, para pakar ramai menyatakan bahwa dunia ini akan semakin kompleks dan saling ketergantungan (interdependence). Dikatakan juga bahwa perubahan yang akan terjadi dalam bentuk nonlinier, tidak bersambung (discontinuons) dan tidak
Dan sekarang ini dunia telah berada dalam kesepakatan bahwa abad ke-21 akan diselimuti oleh alam perdagangan bebas dan globalisasi, dimana kompetisi antara individu, antara negara dan antar usaha akan semakin tajam. Demikian pula keterbukaan demokrasi, masalah Hak-Hak Asasi Manusia (HAM), Hak atas Keyakinan Intelektual (HaKI) dan masalah lingkungan hidup akan menjadi agenda pokok di abad ke-21. Dunia secara global pada abad 21 ini, telah memihak pada kepentingan pasar. Sebagaimana sudah kiata ketahui mulai tahun 2003 kemarin, kita sudah memasuki era perdagangan bebas ASEAN, yang secara formal diratifikasi dalam AFTA pada tahun 2010. Dan tahun 2020 memasuki era perdagangan bebas dalam konteks kerjasama Asia dan fasifik (APEC). Maka millinium ketiga, kita berada dalam arus besar kehidupan yang berparadigma kapitalisme. Begitu juga dalam dunia pendidikan yang merupakan subsistem dari struktur sosial, juga tidak terlepas dari pengaruh arus besar kosmos kapitalisme ${ }^{5}$ serta

bisa sinambungan (a series of discontinuities). Kita memerlukan pemikiran ulang (rethinking) dan rekayasa ulang (reengineering) terdapat masa depan tersebut. Kita harus berani meninggalkan pemikiran dan cara-cara lama yang kurang cocok dan tidak produktif. The road stop here; Where we go next? Kesemua pertanyaan tersebut menggambarkan kekhawatiran dunia akan kekurangsiapan kita dan juga merupakan dorongan untuk mempersiapkan diri dalam menghadapi globalisasi. Lihat dalam Husni Rahim, Arah baru Pendidikan Islam di Indonesia, (Jakarta: Logos, cet- I, 2001), 127.

5 Artinya bahwa pendidikan yang pada hakekatnya adalah hak asasi manusia yang sangat penting eksistensinya dalam perjalanan peradaban umat manusia, berubah menjadi suatu komoditas, bagi mereka yang memiliki uang dan mampu untuk membayarnya, akan menikmati pelayanan dan mutu pendidikan, sementara bagi mereka yang tidak mampu membayar pendidikan tidak akan mendapat akses dan pelayanan pendidikan. Pendidikan yang sejak lama menjadi usaha untuk mempertahankan 
kondisi masyarakat yang sudah menjadi rimba hedonisme.

Untuk bisa survive dan berjaya di tengah perkembangan dunia yang kian kompetitif di masa kini dan abad ke-21, pondok pesantren telah memiliki esensi dasar yang tidak bisa lepas dari karakteristik pesantren, yaitu lembaga pendidikan yang selalu dan senantiasa menekankan pentingnya moral akhlaqul karimah sebagai pedoman hidup bermasyarakat sehari-hari. Moral yang dimaksud dinsini adalah tasawuf. Dengan demikian tasawuf adalah inti Islam. Disinilah titik temu antara tasawuf dan pesantren. Sebab esensi tasawuf adalah pada pengejawan ihsan, sementara itu esensi pesantren terletak pada pembinaan kepribadian muhsin, maka sudah sewajarnya jika tasawuf telah menjadi tiang penyangga berdirnya pondok pesantren atau tasawuf sebagai subkultur pondok pesantren. ${ }^{6}$

Berangkat dari uraian di atas, judul penelitian ini adalah PESANTREN, TASAWUF DAN HEDONISME KULTURAL (Studi Kasus pada Pondok Modern Darussalam Gontor).

\section{Fokus dan Tujuan Penelitian}

Berangkat dari fenomena di atas, fokus penelitian ini adalah bagaimanakah aktualisasi nilai-nilai tasawuf dalam hidup dan kehidupan di

eksistensi dan budaya manusia, saat ini tengah mengalami pergeseran orientasi, visi maupun ideologi yang berakibat ancaman bagi eksistensi manusia sendiri. Lihat dalam Francis Wahono, Kapitalisme Pendidikan: Antara Kompetensi dan Keadilan, (Celeban Timur: Insist Press, Cindelaras, cet ke-1, 2001), xvi.

6 Nidhaman Ni'am, Tasawuf dan Krisis, (Yokyakarta: Pustaka Pelajar: Anggota IKAPI, 2001), 175-176.
Pondok Modern Darussalam Gontor. Sedangkan tujuan penelitian ini adalah untuk mendeskripsikan dan memaknai aktualisasi nilai-nilai tasawuf dalam hidup dan kehidupan pada Pondok Modern Darussalam Gontor.

\section{Manfaat Penelitian}

Manfaat dari penelitian ini adalah ditemukannya pola aktualisasi nilainilai tasawuf dalam hidup dan kehidupan di pendidikan global yang ber-paradigma dan ber-ideologi kapitalisme.

\section{Metodologi Penelitian}

Untuk mendeskripsikan fokus penelitian tersebut diatas, digunakan metodologi penelitian kualitatif yaitu prosedur penelitian yang menghasilkan data deskriptif berupa kata-kata tertulis atau lisan dari orang-orang-orang dan perilaku yang dapat dialami yang menggunakan latar alami (natural setting) sebagai sumber data langsung dan peneliti sendiri merupakan instrumen kunci. Sedangkan instrumen lain sebagai instrumen penunjang. Maka data yang dikumpulkan atau disajikan dalam bentuk kata-kata dan gambargambar. Laporan penelitian memuat kutipan-kutipan data sebagai ilustrasi dan dukungan fakta pada penyajian. Data tersebut mencakup transkip wawancara, catatan lapangan, dan dokumentasi serta rekaman dan dokumen lainnya. Dan dalam memahami fenomena, peneliti berusaha melakukan analisis sekaya mungkin mendekati bentuk data yang telah direkam. Dalam penelitian ini analisis dilaksanakan dua kali, yaitu analisis data selama pengumpulan data dan setelah pengumpulan data. dengan menggunakan analisis domain dan 
analisis taksonomi serta analisis komponensial.

\section{Kerangka Teoritik TASAWUF}

Tasawuf merupakan salah satu aspek perwujudan dari ihsan, yang berarti kesadaran adanya komunikasi dan dialog langsung seorang hamba dengan Tuhan-Nya. ${ }^{7}$ Dalam dunia tasawuf, seorang yang ingin bertemu dengan-Nya, harus melakukan perjalanan (suluk) dan menghilangkan sesuatu yang menghalangi antara dirinya dengan Tuhan-Nya, yaitu dunia materi. Dalam tasawuf sikap ini disebut zuhud (keadaan meninggalkan dunia dan hidup kematerian).

Zuhud merupakan maqam terpenting dalam tasawuf. Secara eksplisit kata zuhud dalam Al-Qur'an hanya disebut sekali, yaitu dalam Q.S Yusuf 20, namun sikap zuhud banyak disebut dalam berbagai ayat al-Qur'an. Secara keseluruhan ayat-ayat yang berkaitan dengan sikap manusia terhadap dunia diklasifikasikan menjadi dua. ${ }^{8}$ Pertama, Ayat-ayat yang menganggap negatif terhadap dunia dan menganjurkan agar manusia mengisolasikan diri daripadanya. Model ayat seperti ini menyoroti sikap manusia pada umumnya dan orang-orang kafir pada khususnya yang hanya mencari kesenangan di dunia ini saja, dan mengharapkan kekekalan hidup di dalamnya. Kedua, Ayat-ayat yang menyatakan bahwa dunia diciptakan oleh Allah SWT, bukan hanya sekedar

\footnotetext{
${ }^{7}$ Nasution, Harun, Filsafat dan Mistisisme dalam Islam, (Jakarta: Bulan Bintang, 1995), 62

${ }^{8}$ Syukur, HM. Amin, Zuhud di Abad Modern, (Yokyakarta: Pustaka Pelajar: Anggota IKAPI, cet ke-2, 2000), vii.
}

sambil lalu (la'ibun), tetapi mempunyai makna, hikmah dan tujuan yang jelas dan positif (haq). Karena itu seorang mukmin tidak dilarang menikmatinya secara wajar dan proporsional, sepanjang tidak mengalahkan akhirat dan melupakan Allah SAW.

Model klasifikasi ayat pertama mengedepankan makna zuhud, bahwa seorang zahid harus isolatif, eksklusif atau reaktif dalam mensikapi dunia nyata, sebagaimana yang telah dipraktekkan oleh beberapa tokoh sufi masa lalu. Sedangkan model klasifikasi ayat kedua bahwa seorang zahid harus mampu bersikap integratif, inklusif dan mendunia, sehingga penerapan sikap zuhudnya betul-betul fungsional dan mampu menjawab problem keduniaan yang dirasakan semakin rumit. Maka apabila seseorang menggunakan landasan model ayat kedua, maka setiap orang Islam dilarang mengisolasikan diri dari kehidupan ini dan eksklusif. Sebaliknya mereka wajib bekerja keras, mencari bekal hidup di dunia dan hasilnya diperuntukkan bagi kebaikan. Dunia ini tempat berkiprah dengan amal sholeh, yang hasilnya akan dipetik kelak di akhirat. Kiprah mereka di dunia ini sejalan dengan fungsi kekhalifahannya yang mempunyai tugas untuk memakmurkan, menegakkan kebenaran dan keadilan, motivator dan dinamisator pembangunan, sebagaimana tersirat dalam firman Allah SWT Q.S al-Qashah ayat 77 tentang keseimbangan antara hidup di dunia dan akhirat.

Sikap manusia terhadap dunia sebagaimana pada model ayat klasifikasi kedua merupakan yang ampuh bagi manusia dalam menghadapi kehidupan, khususnya di abad modern yang sarat dengan problema, baik psikis, ekonomis 
dan etis. Zuhud dapat dijadikan sebagai benteng membangun diri dalam menghadapi gemerlapnya materi atau pengultusan duniawi (hedonisme).

\section{Tasawuf Akhlaqi}

Tasawuf Akhlaqi adalah ajaran Tasawuf yang membahas tentang kesempurnaan dan kesucian jiwa yang diformulasikan pada pengaturan sikap mental dan pendisiplinan tingkah laku yang ketat, guna mencapai kebahagiaan yang optimal, manusia harus lebih dahulu mengidentifikasikan eksistensi dirinya dengan ciri-ciri ketuhanan melalui penyucian jiwa raga yang bermula dari pembentukan pribadi yang bermoral paripurna dan berakhlak mulia yang dalam ilmu tasawuf dikenal dengan takhalli (pengosongan diri dari sifat-sifat tercela), tahalli (menghiasi diri dengan sifat-sifat terpuji), dan tajalli (terungkapnya nur ghaib bagi hati yang telah bersih sehingga mampu menangkap cahaya ketuhanan). ${ }^{9}$ Takhalli, berarti membersihkan diri dari sifat-sifat tercela, kotoran dan penyakit hati yang merusak. Langkah pertama yang harus ditempuh adalah mengetahui dan menyadari, betapa buruknya sifat-sifat tercela dan kotor tersebut, sehingga muncul kesadaran untuk memberantas dan menghindarinya. Apabila hal ini bisa dilakukan dengan sukses, maka seorang akan memperoleh kebahagiaan. Tahalli, berarti menghiasi diri dengan jalan membiasakan dengan sifat dan sikap serta perbuatan yang baik. Berusaha agar dalam setiap gerak dan

${ }^{9}$ H.M. Amin Syukur \& H. Masyaruddin, Intelektualisme Tasawuf al-Ghazali (Yogyakarta: Pustaka Pelajar, 2002), 45 perilakukunya selalu berjalan diatas ketentuan agama. langkahnya ialah membina pribadi, agar memiliki akhlak al-karimah dan senantiasa konsisten dengan langkah-langkah yang dirintis sebelumnya (dalam ber-takhalli). Melakukan latihan kejiwaan yang tanggunh untuk membiasakan berperilaku baik, yang pada gilirannya akan menghasilkan manusia yang sempurna. Tajalli, yakni apabila seseorang hatinya terbebaskan dari tabir (hijab), yaitu sifat-sifat kemanusiaan atau memperoleh nur yang selama ini tersembunyi (ghaib) atau fana' segala selain Allah ketika nampak (tajalli) wajah-Nya. ${ }^{10}$ Tajalli dibagi menjadi empat tingkatan, yaitu (1) Tajalli alAf'al, yakni tajalli-Nya pada perbuatan seseorang, artinya segala aktifitas itu disertai kudrat dan iradat-Nya, dan ketika itu dia melihat-Nya. Hal ini bisa berarti bahwa gerak dan diam itu adalah atsar (bekas) dari kodrat dan iradat-Nya; (2) Tajalli al-Asma', yakni lenyapnya seseorang dari dirinya dan bebasnya dari genggaman sifat-sifat kebaharuan, dan lepasnya dari ikatan tubuh kasarnya. Pada lingkungan ini tiada yang dilihat kecuali dzat al-Shirfah (hakekat gerak), bukan melihat asma'; (3) Tajalli Sifat, yakni seseorang hamba menerima sifat-sifat ketuhanan, artinya Tuhan mengambil tempat padanya tanpa hulu dzat-Nya; (4) Tajalli Dzat, yakni apabila Allah menghendaki adanya tajalli atas hamba-Nya yang mengfana'kan dirinya, maka bertempatlah Dia padanya, yang berupa sifat dan bisa berupa dzat. Apabila berupa dzat, maka disitulah terjadi

${ }^{10}$ Mustafa Zahri, Kunci Memahami Ilmu Tasawuf, (Surabaya: Bina Ilmu, 1979), 245. 
"ketunggalan" yang sempurna. Dengan fana'nya seseorang hamba , maka yang baqa' hanyalah Dia. Dalam pada itu, hamba telah berada dalam situasi ma suwailah, yakni dalam wujud Allah semata. ${ }^{11}$

\section{Tasawuf Amali}

Tasawuf Amali adalah tasawuf yang membahas tentang bagaimana cara mendekatkan diri kepada Allah. Dalam pengertian ini tasawuf amali berkonotasi tarekat. Tarekat dibedakan antara kemampuan sufi yang satu daripada yang lain. Ada orang yang dianggap mampu dan tahu cara mendekatkan diri kepada Allah, dan orang yang memerlukan bantuan orang lain yang dianggap memiliki otoritas dalam masalah itu. Dalam perkembangan selanjutnya, para pencari dan pengikut semakin banyak dan terbentuklah semacam komunitas sosial yang sefaham dan dari sini muncullah strata-strata berdasarkan pengetahuan serta amalan yang mereka lakukan. Dari sini maka muncullah istilah murid, mursyid, wali dan sebagainya. ${ }^{12}$

Oleh karena itu dalam tarekat ada tiga unsur, yakni guru (Mussyid), murid dan ajaran. Guru adalah orang yang mempunyai otoritas dan legalitas kesufian yang berhak mengawasi muridnya dalam tingkah laku dan geraknya sesuai dengan ajaran Islam. Oleh karena itu dia mempunyai keistimewaan khusus, seperti jiwa yang bersih.

${ }^{11}$ Abdul Karim al-Jilli, Insan al-kamil fi Ma'rifah al-Awakhir wa al-Awa'il, (Kairo: Dar al-Fikr, 1975), 56-73

${ }_{12}$ H.M. Amin Syukur \& H.Masyaruddin, Intelektualisme Tasawuf al-Ghazali (Yogyakarta: Pustaka Pelajar, 2002), 50

\section{TAswuf Falsafi}

Tasawuf falsafi, yaitu tasawuf yang ajaran-ajarannya memadukan antara visi intuitif dan visi rasional. Terminologi filosofis yang digunakan berasal dari bermacam-macam ajaran filsafat yang telah mempengaruhi para tokohnya, namun orisinalitasnya sebagai tasawuf tetap tidak hilang. Walaupun demikian tasawuf filosofis tidak bisa dipandang sebagai filsafat, karena ajaran dan metodenya didasarkan pada rasa (dzauq), dan tidak pula bisa dikatagorikan pada tasawuf (yang murni) karena sering diungkapkan dengan bahasa filsafat. ${ }^{13}$

Dalam upaya mengungkapkan pengalaman rohaninya, para sufi falsafi sering menggunakan ungkapanungkapan yang samar-samar, yang dikenal dengan syathahat, yaitu suatu ungkapan yang sulit difahami, yang sering kali mengakibatkan kesalahfahaman pihak luar, dan menimbulkan tragedi. Tokoh-tokohnya adalah Abu Yazid al-Bushthami, al-Hallaj, dan sebaginya.

\section{Tasawuf sebagai Sub-Kultur Pesantren}

Sebagaimana telah dikatahui bahwa, ada golongan umat Islam yang belum merasa puas dengan pendekatan diri kepada Tuhan melalui ibadah shalat, puasa dan haji. Sebenarnya golongan tersebut ingin merasa lebih dekat lagi dengan Tuhan. Dalam hal ini, jalan yang harus ditempuh untuk menuju pendekatan diri dimaksud diberikan oleh tasawuf, karena tujuan

\footnotetext{
${ }^{13} \mathrm{Abu}$ al-Wafa al-Ghanimi al-Taftazani, Madkhal ila al-Tasawuf al-Islami (Kairo: Dar al-Tsaqafah, 1979), 187-188
} 
dari orang-orang tasawuf adalah berada sedekat mungkin dengan Tuhan untuk memperoleh ma'rifat dan keridhaanNya, bahkan ada sebagian yang ingin mencapai persatuan dengan-Nya. ${ }^{14}$

Pada waktu itu umat Islam mengalami kemunduran, baik dalam bidang politik, militer, ekonomi dan kegiatan intelektual pada abad $12 \mathrm{M}$, maka gerakan-gerakan orang tasawuflah yang dapat memilihara jiwa keagamaan di kalangan umat Islam. mereka menjadi perantara bagi tersebarnya agama Islam keluar dari daerah Timur Tengah, termasuk Asia Tenggara. Para pedagang, pengembara dan pengamal tasawuf merupaka juru tabligh utama penyebaran Islam, terutama di Indonesia. ${ }^{15}$ Dalam hal ini Martin van Bruinessen menegaskan bahwa Islamisasi di Indonesia berawal ketika tasawuf merupakan corak pemikiran yang dominan di dunia Islam. Pikiran-pikiran para sufi terkemuka, seperti Ibnu Arabi dan AlGhazali sangat berpengaruh terhadap pengarang-pengarang Muslim generasi pertama di Indonesia, yang hampir semuanya menjadi pengikut suatu tarekat. ${ }^{16}$ Pusat-pusat ajaran Islam yang pertama kali, khususnya di Jawa seperti di daerah Ampel dan Giri agaknya merupakan sambungan system zawiyah di Timur Tengah, yang kemudian berkembang menjadi pondok pesantren.

Meskipun pondok pesantren merupakan perkembangan dari sistem zawiyah yang dikembangkan kaum sufi,

\footnotetext{
${ }^{14}$ Harun Nasution, Islam Ditinjau dari berbagai Aspeknya, jilid II (Jakarta: UI-Press, 1986), 78

${ }^{15}$ Nurcholis Madjid, Bilik-bilik Pesantren; Sebuah Potret Perjalanan (Jakarta: Paramadina, 1997), 54-55.

${ }^{16}$ Martin Van Bruinessen, Tarekat Naqsabandiyah di Indonesia: Survei Historis, Geografis dan Soisologis, (Bandung: Mizan, 1992), 15
}

bukan berarti setiap pesantren merupakan pusat gerakan tasawuf. Bahkan, pesantren yang melakukan peran sebagai pusat gerakan tarekat hanyalah sedikit. Pada umumnya pondok pesantren berfungsi sebagai lembaga pendidikan dan penyiaran agama Islam, terutama dalam memelihara dan mengembangkan faham Islam tradisional, yaitu Islam yang masih terikat kuat dengan pikiranpikiran para ulama' ahli fiqih, hadis, tafsir, tauhid. ${ }^{17}$

Sebenarnya bidang tasawuf paling menarik dalam struktur kehidupan beragama, tetapi sedikit sekali pesantrenpesantren yang secara sungguhsungguh menggarapnya. Padahal tasawuf ini merupakan bidang yang sangat potensial untuk memupuk rasa keagamaan para santri, dan menuntun mereka memiliki budi pekerti mulia. Mengingat tasawuf merupakan tulang punggung pesantren atau tiang penyangga pesantren dalam rangka membina akhlak mulia, maka dapat dinyatakan bahwa pesantren merupakan lembaga pemelihara dan pengembang esensi tasawuf, sebagai subkulturnya.

Esensi Tasawuf pada hakekatnya adalah tashfiyah al-qalb 'an al-shifat almadzmumah, yang berarti membersihkan hati dari sifat-sifat yang tercela. Oleh karena itu yang menjadi sasaran tasawuf adalah hati, atau jiwa, atau rohani, atau batin yang menjadi sumber segala sikap dan tingkah laku manusia untuk menuju kebersihan hati agar memperoleh keridhaan Tuhan. Dengan demikian dapat dikatakan bahwa

${ }_{17}$ Zamakhsyari Dhofier, Tradisi Pesantren: Studi Tentang Pandangan Hidup Kyai (Jakarta: LP3ES, 1985), 1 
tasawuf adalah suatu ajaran dalam Islam yang mengajarkan bagaimana seharusnya seseorang bersikap mental dalam hubungannya dengn Tuhan, dengan sesama manusia dengan alam lingkungannya yang didasarkan petunjuk Al-Qur'an dan Al-Sunnah.

Tasawuf disini meliputi dua macam bentuk, yaitu tasawuf 'ammah (yang umum) dan tasawuf yang khashhah (yang khusus). Yang pertama berupa semua bentuk kegiatan dalam usaha peningkatan moral dan akhlak, yaitu meliputi segala perbuatan baik yang dilakukan dengan istiqamah, seperti: shalat, wirid, infak, sedekah, menolong orang lain, amar ma'ruf nahi mungkar, bahkan juga kegiatan mencari nafkah dengan didasari niat yang benar. Yang kedua berupa semua kegiatan tata wirid yang dipraktekkan secara istiqamah, yang diterima dari guru-guru tertentu yang berkesinambungan secara muttasil sampai kepada Rasulullah SAW.

H.M. Amin Syukur, dalam suatu hasil penelitiannya, menyebutkan bahwa tasawuf adalah kesadaran adanya komunikasi dan dialog langsung antara seseorang Muslim dengan Tuhan. Tasawuf juga merupakan suatu system latihan dengan penuh kesungguhan untuk membersihkan, mempertinggi dan memperdalam kerohanian dalam rangka mendekatkan diri kepada Allah. Sehingga dengan itu, maka segala konsentrasi seseorang hanya tertuju kepada-Nya. ${ }^{18}$

Dengan perkataan lain dapat dinyatakan bahwa esensi tasawuf

${ }^{18}$ Amin Syukur, Tasawuf dan Tanggung Jawab Sosial, (Semarang: Pusat Penelitian IAIN Walisongo Semarang, Laporan Penelitian Tahun 1996/1997), 19 terletak pada pengejawantahan dari ajaran tentang ihsan, salah satu dari tiga serangkai ajaran Islam, yaitu, islam sendiri, iman dan ihsan. Esoterisme sufi adalah perwujudan dari sabda Nabi sendiri bahwa ihsan adalah keadaan dimana ketika kita menyembah Allah seolah-olah kita melihat-Nya, dan kalaupun kita tidak melihatNya, maka Dia yang melihat kita. Apa yang diajarkan tasawuf tidak lain adalah bagaimana menyembah Allah dengan suatu kesadaran penuh bahwa kita berada di dekat-Nya sehingga kita "melihat" Nya atau bahwa Dia senantiasa mengawasi kita dan kita senantiasa berdiri dihadapan-Nya. ${ }^{19}$

Sementara itu mengenai esensi tasawuf menurut Prof. Dr. Simuh, pada dasarnya terdapat dua pandangan yang berbeda, yaitu pertama, memandang esensi tasawuf pada ajaran zuhud, yaitu ajaran untuk bertekun dalam beribadah serta membelakangi kemewahan dan perhiasan duniawi. Kedua, memandang esensi tasawuf pada upaya untuk memperoleh penghayatan fana' dan ma'rifat secara langsung terhadap dzat Tuhan, yakni mencapai penghayatan face to face atau bahkan bersatu dengan Tuhan di dalam suasana extasy (fana dan ma'rifat). ${ }^{20}$

Dengan demikian dapat dinyatakan bahwa esensi tasawuf terletak pada pengejawantahan al-Ihsan, zuhud dan penghayatan fana dan ma'rifat. Dalam hal ini kaum sufi banyak memiliki perumpamaan mengenai kebulatan

${ }^{19}$ Nurcholis Madjid, Bilik-bilik Pesantren; Sebuah Potret Perjalanan, 134. Lihat juga, K.H. Syamsuri Badawi, "Tarekat, Suatu keniscayaan", dalam pesantren, No. 3/Vol. II/ 1985, 38.

${ }^{20}$ Simuh, "Antara Tasawuf dan Batiniah" dalam Pesantren, Ibid.,,13. 
agama Islam yang tidak dapat terpishkan, yaitu terdiri dari syari'at, thariqat dan hakekat. Ibarat buah kacang, syari'at adalah kulitnya, thariqat adalah bijinya, dan haqiqah adalah minyaknya yang sekalipun tidak tampak tetapi terdapat di mana-mana. Kacang tanpa ketiga unsurnya itu tidak dapat tumbuh jika ditanam di ladang. Begitu juga tasawuf tidak akan memberi kegunaan rohani jika tidak mencakup ketiga bagiannya yang integral tersebut.

Dalam hal ini Imam Malik menyatakan bahwa, pertama, siapa yang mengamalkan fiqih tanpa bertasawuf maka dia adalah fasiq (tidak bermoral), kedua, siapa yang bertasawuf tanpa mengamalkan fiqh maka dia adalah zindiq (menyeleweng), dan ketiga, siapa yang menggabungkan keduanya maka dia telah berhaqiqah (menemukan kebenaran). ${ }^{21}$

Sedanagkan Esensi Pondok Pesantren adalah diartikan sebagai lembaga pendidikan tradisional Islam untuk mempelajari, memahami, mendalami, menghayati dan mengamalkan ajaran Islam dengan menekankan pentingnya moral keagamaan sebagai pedoman perilaku sehari-hari. ${ }^{22}$ Pondok, masjid, santri, pengajaran kitab-kitab kitab-kitab Islam klasik dan kyai adalah merupakan elemen dasar dari pondok pesantren. Kyai merupakan unsur yang paling esensial dari suatu pesantren, bahkan seringkali merupakan pendirinya. Oleh karena itu sudah sewajarnya jika petumbuhan suatu pesantren bergantung kepada kemampuan pribadi kyai. ${ }^{23}$ Ia sebagai

${ }^{21}$ Nur Chalish Madjid, Bilik-bilik Pesantren; Sebuah Potret Perjalanan, 57-58.

${ }^{22}$ Lihat Mastuhu, Dinamika Sistem Pendidikan Pesantren (Jakarta: INIS, 1994), 55.

${ }^{23}$ Zamakhsyari Dhafir, Tradisi Pesantren, 55. tokoh kunci yang menentukan corak kehidupan pesantren.

Adapun tujuan pendidikan pesantren adalah menciptakan dan mengembangkan kepribadian muslim, yaitu kepribadian beriman dan bertaqwa kepada Tuhan, berakhlak mulia, bermanfaat bagi masyarakat atau berkhidmad kepada masyarakat dengan jadi kawulo atau abdi masyarakat tetapi rasul, yaitu menjadi pelayan masyarakat sebagaimana kepribadian Nabi Muhammad SAW (mengikuti sunah Nabi), mampu berdiri sendiri, bebas dan teguh dalam kepribadian, menyebarkan agama atau menegakkan Islam dan kejayaan umat Islam di tengah-tengah masyarakat dan mencintai ilmu dalam rangka mengembangkan kepribadian Indoinesia. Idealnya pengembangan kepribadian yang ingin dituju ialah kepribadian muhsin bukan sekedar muslim. $^{24}$

Dengan demikian dapat dinyatakan bahwa esensi dari pesantren adalah pembinaan kepribadian muhsin, yakni melaksanakan ihsan dalam arti yang sesungguhnya.

\section{Paparan Data}

KH.Imam Zarkasyi sebelum mendirikan lembaga pendidikan Gontor dengan corak yang modern, beliua bersama pendiri pondok Gontor lainnya, telah mengkaji lembagalembaga pendidikan yang terkenal dan maju di luar negeri, ${ }^{25}$ khususnya yang sesuai dengan sistem pondok pesantren.

\footnotetext{
${ }^{24}$ Mastuhu, Dinamika Pesantren, 55-56

${ }^{25}$ Pertama, Universitas al-Azhar, Mesir, yang terkenal karena wakafnya dan kelanggengannya. AlAzhar bermula dari sebuah mesjid sederhana namun kemudian dapat hidup ratusan tahun dan telah memiliki tanah wakaf yang mampu memberi beasiswa untuk mahasiswa seluruh dunia. Kedua, pondok syanggit di Afrika Utara, dekat Libya. Lembaga dikenal karena
} 
Dari lembaga pendidika yang dikunjungi itu yang menjadikan idaman Imam Zarkasyi dan lembaga pendidikan yang hendak ia bangun adalah pondok pesantren yang merupakan perpaduan antara sintesa dari keempat unsur di atas. Semua dipadukan dalam pandangan agama yang tergolong Mazhab Ahlussunah Wal-Jama'ah yang mayoritas dianut umat Islam di Indonesia. Pada seminar pondok pesantren se-Indonesia tahun 1965 di Yogyakarta, Imam Zarkasyi merumuskan jiwa pesantren itu ada lima yang disebutnya dengan PANCA JIWA, yaitu Jiwa keikhlasan, Jiwa kesederhanaan, Jiwa kesanggupan menolong diri sendiri (self help) atau berdikari, Jiwa ukhuwah Islamiyah dan Jiwa yang bebas. ${ }^{26}$

Lima nilai-nilai menurut tersebut menurut KH.Imam Zarkasy dan pendiri lainNya yang harus dijadikan sebagai jiwa semua kehidupan di Pondok Modern Gontor, sebagaimana hasil wawancara peneliti dengan salah satu ustadz Pondok Modern Darussalam Gontor Ust. Abdullah Rafi, M.Ag yang

kedermawanan dan keihklasan pengasuhnya. Pondok ini dikelola dengan jiwa ikhlas dan pengasuhnya disamping mendidik murid-muridnya, juga menanggung kebutuhan hidup sehari-hari mereka. Ketiga, Universitas Muslim Aligarch yang membekali mahasiswanya dengan pengetahuan umum dan agama sehingga mereka mempunyai wawasan yang luas dan menjadi pelopor kebangkitan Islam di India. Keempat, masih juga di India, yaitu perguruan Shantiniketan yang didirikan oleh seorang filosof Hindu, Rabendranath Tagore. Perguruan ini dikenal karena kedamaiannya, dan meskipun terletak jauh dari keramaian, tetapi dapat melaksanakan pendidikan dengan baik dan bahkan mempengaruhi dunia. Kedamaian di perguruan tersebut mengilhami Darussalam (kampung damai) untuk pondok pesantren Gontor

${ }^{26}$ Lihat dalam Booklet Pondok Modern Gontor Ponorogo Indonesia, yang ditulis oleh KH. Abdullah Syukri Zarkasyi, KH. Hasan Abdullah Sahal, dan KH. Imam Badri pada Tahun 2000. dikutip dari penrnyataan $\mathrm{KH}$. Abdullah Syukri adalah sebagai berikut

Hal yang paling penting dalam pesantren bukanlah pelajarannya semata-mata, melainkan jiwanya. Jiwa itulah yang akan memelihara kelangsungan hidup pesantren dan menentukan filsafat hidup para santrinya. ${ }^{27}$

Aktualisasi dan pemberdayaan nilainilai tersebut terlihat dalam kehidupan sehari-hari santri dan pimpinan serta pengurus Pondok Modern Gontor. Hasil observasi, wawancara dan dokumentasi telah menunjukkan adanya aktualisasi dan pemberdayaan nilai-nilai tersebut, dengan paparan deskriptif sebagai berikut.

Aktualisasi Nilai-nilai "Jiwa Keikhlasan" dalam Hidup dan Kehidupan di Pondok Modern Darussalam Gontor.

Yang dimaksud dengan "Jiwa Keikhlasan" sebagai jiwa Pondok Modern Darussalam Gontor yang akan memelihara kelangsungan hidup pesantren dan menentukan filsafat hidup para santrinya yaitu sebagaimana yang dirumuskan oleh KH.Imam Zarkasy bahwa yang dimaksud dengan jiwa keikhlasan adalah :

Sepi ing pamrih (tidak didorong oleh keinginan memperoleh keuntungan-keuntungan tertentu), tetapi semata-mata karena ibadah, karena Allah. Hal ini meliputi segenap suasana kehidupan di pondok pesantren. Kyai ikhlas dalam mengajar, para santri ikhlas dalam belajar, lurah pondok ikhlas dalam membantu (asistensi). Segala gerak-gerik

\footnotetext{
${ }^{27}$ Ibid.
} 
dalam pondok pesantren berjalan dengan suasana keikhlasan yang mendalam. dengan demikian terdapatlah suasana hidup yang harmonis, antara kyai yang disegani dan santri yang taat dan penuh cinta serta hormat. ${ }^{28}$

Apa yang telah dirumuskan oleh Pimpinan Pondok Modern Darussalam Gontor tersebut tentang konsep-konsep "jiwa keikhlasan" selalu diaktualisasikan dalam semua aktifitas, baik aktifitas harian, mingguan, maupun bulanan, sebagaimana hasil observasi dan dokumentasi peneliti yang mencatat bahwa setiap mudabbir rayon yang setiap pagi melakukan tugas membangunkan anggotanya, tanpa kenal lelah dan tanpa pamrih. Hal tersebut dilakukan tidak hanya "sekedar" melakukan kewajiban akan tetapi sebuah pengabdian dan amanat yang harus dilakukan dan dijunjung tinggi tanpa mengharap apapun. Demikian pula mudabbir yang berdiri di depan masjid, menyuruh para santri untuk bergegas dan bersegera ke masjid, kemudian menertibkan shaf santri di dalam masjid. Hal tersebut dilakukannya setiap hari. Tidak ada kata lelah dan bosan. Semua itu dilakukan semata-mata karena amanat yang diberikan kepadanya oleh pimpinan pondok yang tentunya pertanggungjawabannya tidak semata-mata kepada pimpinan akan tetapi kepada Allah. Para ustadz yang yang pagi mengajar dan malam masih harus berkeliling mengawasi dan mengontrol belajar santri kalau dipikir tentu sangat capek dan melelahkan. Apalagi kalau dihitung secara materi tentu tidak sebanding apa yang sudah mereka kerjakan dengan

${ }^{28}$ Ibid. apa yang mereka peroleh. Tetapi kesemangatan, ketulusan nampak dari wajah-wajah mereka. Tidak ada beban berat yang dirasakan. Semua dilakukan karena tanggung jawab dan sadar akan arti sebuah pengabdian. ${ }^{29}$

\section{Aktualisasi Nilai-Nilai "Jiwa KesederhanaAN" dalam Hidup dan Kehidupan di PondoK Modern Darussalam Gontor. \\ Yang dimaksud dengan "Jiwa} Kesederhanaan" sebagai jiwa Pondok Modern Darussalam Gontor yang akan memelihara kelangsungan hidup pesantren dan menentukan filsafat hidup para santrinya yaitu sebagaimana yang dirumuskan oleh KH.Imam Zarkasy bahwa yang dimaksud dengan "Jiwa Kesederhanaan" adalah:

Dalam kehidupan di pesantren harus diliputi suasana kesederhanaan tetapi tetap agung. Sederhana bukan berarti pasif nrimo (pasrah) dan bukan karena melarat atau miskin, tetapi mengandung kekuatan dan ketabahan dalam diri, penguasaan diri dalam menghadapi segala kesulitan. Dengan demikian, dibalik kesederhanaan itu terpancar jiwa besar, berani maju dalam menghadapi perjuangan hidup dan pantang mundur dalam segala keadaan. Bahkan disinilah hidup tumbuhnya mental/karakter yang kuat yang menjadi syarat bagi suksesnya perjuangan dalam segala segi kehidupan. ${ }^{30}$

${ }^{29}$ Hasil observasi peneliti di lokasi penelitian tanggal 7 April 2004.

${ }^{30}$ Lihat dalam Booklet Pondok Modern Gontor Ponorogo Indonesia, yang ditulis oleh KH. Abdullah Syukri Zarkasyi, KH. Hasan Abdullah Sahal, dan KH. Imam Badri pada Tahun 2000. 
Apa yang telah dirumuskan oleh Pimpinan Pondok Modern Darussalam Gontor tersebut tentang konsep-konsep "Jiwa Kesederhaanan" selalu diaktualisasikan dalam semua aktifitas santri, sebagaimana hasil observasi dan dokumenatsi peneliti bahwa dari cara berpakaian santri sama sekali tidak mencerminkan sebuah kemewahan, dengan baju yang polos namun tidak mengesampingkan aspek keindahan dan kebersihan. Model baju dengan corak dan motif seperti itu kira-kira harganya juga tidak terlalu mahal, artinya adalah bahwa hampir siapapun mampu membelinya. Warna dan motif baju seperti itu memang disisi lain akan meniadakan jarak yang bagaimanapun mesti ada antara santri yang kelas ekonomi orang tuanya tinggi dengan santri yang orang tuanya pas-pasan. Rasa tanggungjawab yang diberikan oleh para mudabbir kepada para santri adalah sebuah nilai yang juga ingin di tanamkan pada diri santri. Seperti bagaimana para santri menyapu dan mengepel kamar serta rayon, mengambilkan nasi bagi kawannya yang sakit, itu semua adalah cerminan dari bagaimana mereka memiliki tanggungjawab terhadap diri dan lingkungannya. Kesahajaan santri juga nampak ketika mereka harus membawa piring ke dapur untuk makan bersamasama dengan kawan-kawan mereka. Mereka tidak malu dan minder meski harus membawa piring sendiri dan harus santri untuk mengambil nasi di dapur. $^{31}$

${ }^{31}$ Hasil observasi peneliti di lokasi penelitian tanggal 7 April 2004.

\section{Aktualisasi Nilai-Nilai "Jiwa BERDIKARI" DALAM HIDUP DAN Kehidupan di Pondok Modern Darussalam Gontor.}

Yang dimaksud dengan "Jiwa Berdikari" sebagai jiwa Pondok Modern Darussalam Gontor yang akan memelihara kelangsungan hidup pesantren dan menentukan filsafat hidup para santrinya yaitu sebagaimana yang dirumuskan oleh KH.Imam Zarkasy bahwa yang dimaksud dengan jiwa berdikari adalah:

Jiwa kesanggupan menolong diri sendiri (self help) atau berdikari; didikan inilah yang merupakan senjata hidup yang ampuh. Berdikari bukan saja dalam arti bahwa santri harus belajar dan berlatih mengurus segala kepentingannya sendiri, tetapi juga pondok pesantren itu sendiri sebagai lembaga pendidikan tidak menyandarkan kehidupannya kepada bantuan dan belas kasihan orang lain. Itulah self bedruiping system (sama-sama memberikan iuran dan sama-sama dipakai) ${ }^{32}$

Apa yang telah dirumuskan oleh Pimpinan Pondok Modern Darussalam Gontor tersebut tentang konsep-konsep "Jiwa Berdikari" selalu diaktualisasikan dalam semua aktifitas di Pondok Modern Darussalam Gontor, sebagaimana hasil observasi peneliti bahwa santri selalu harus mencuci sendiri, membersihkan kamar, melipat kasur sehabis tidur, mencuci piring sehabis makan, dll, kesemuanya adalah sebuah gambaran

${ }^{32}$ Lihat dalam Booklet Pondok Modern Gontor Ponorogo Indonesia, yang ditulis oleh $\mathrm{KH}$. Abdullah Syukri Zarkasyi, KH. Hasan Abdullah Sahal, dan KH. Imam Badri pada Tahun 2000. 
bahwa sesungguhnya santri diajari untuk bagaimana bisa hidup mandiri, menyelesaikan tugas dan kebutuhan diri secara mandiri tanpa harus bergantung pada orang lain. ${ }^{33}$

Disamping itu aktualisasi konsep "Jiwa Berdikari" Pondok Modern Gontor sebagai lembaga pendidikan tidak menyandarkan kehidupannya kepada bantuan dan belas kasihan orang lain adalah sebagaimana hasil dokumentasi peneliti bahwa Pondok Modern Gontor memiliki kekuatan ekonomi yang sangat kuat, dengan terbukti adanya KUK (Koperasi Unit Keluarga) La Tansa di beberapa kota besar di Indoensia, pabrik roti, percetakan, peternakan, pertanian, toko buku, perkebunan dan usaha-usaha kecil lainnya adalah wujud dari jiwa kemandirian pesantren. ${ }^{34}$

Disamping itu kemandirian Pondok Modern Darussalam Gontor, telihat dalam sistem manajemennya. Pimpinan KH Imam Zarkasy telah telah mewakafkan Pondok Modern Gontor kepada sebuah lembaga yang disebut Badan Wakaf Pondok Modern Gontor. Ikrar pewakafan ini telah dinyatakan di muka umum oleh ketiga pendiri Pondok tersebut. Dengan ditandatanganinya Piagam Penyerahan Wakaf itu, maka Pondok Modern Gontor tidak lagi milika pribadi atau perorangan sebagaimana dijumpai dalam lembaga pendidikan pondok pesantrren tradisional. Dengan demikian Pondok Modern Gontor menjadi milik umat Islam, dan umat Islam beratanggungjawab atasnya.

${ }^{33}$ Hasil observasi peneliti di lokasi penelitian tanggal 7 April 2004.

${ }_{34}$ Lihat pada Transkip Rekaman Dokumentasi dalam lampiran penelitian ini, Koding: 01/D/9-V/ 2004.
Lembaga Badan Wakaf ini selanjutnya menjadi badan tertinggi di pondok Modern Gontor. Badan inilah yang bertanggungjawab mengangkat Kyai untuk masa jabatan lima tahun. Dengan demikian kyai bertindak sebagai mandataris dan bertanggung jawab kepada badan wakaf. Untuk itu Badan Wakaf memiliki lima program, yakni yang berkenaan dengan (1) pendidikan dan pengajaran, (2) bidang peralatan dan peregedungan, (3) bidang perwakafan dan sumber dana, (4) bidang kaderisasi, (5) bidang kesejahteraan. Dengan struktur kepengurusan yang demikian, maka kyai dan keluarga tidak punya hak material apapun dari Gontor. Kyai dan guru-guru tidak mengurusi uang dari santri, sehingga mereka tidak pernah membedakan antara santri yang kaya dan yang kurang mampu. Urusan keuangan menjadi tanggungjawab petugas kantor tata usaha yang terdiri dari beberapa orang santri senior dan guru yang secara periodic bisa diganti. Dengan demikian pengatuaran jalannya organisasi pendidikan menjadi dinamis, terbuka dan obyektif. pewakafan Pondok Modern Gontor kepada sebuah lembaga Badan Wakaf Pondok Modern Gontor tersebut didsarkan juga pada pemikiran bahwa pondok pesantren dapat terus akan bertahan dengan memperhatikan syarat-syarat material. Untuk itu harus ada wakaf yang menjadi andalan bagi kelangsungan hidup pondok pesantren. Dengan cara ini, pesantren akan senantiasa dapat meninggikan mutu pendidikan dan pengajarannya; Pondok pesantren tidak akan lupa terhadap program pembentukan kader untuk kelanjutan regenerasi. Sebab seringkali diketahui bahwa hidup matinya pondok 
pesantren seringkali sangat tergantung kepada hidup matinya kyai pendiri pesantren tersebut. Untuk memelihara kelangsungan hidup pondok pesantren sebagai lembaga pendidikan Islam, tiaptiap pondok pesantren harus menyiapkan kader-kader yang akan menggantinya. ${ }^{35}$

\section{Aktualisasi Nilai-Nilai "JiWa UKHUWAH ISLAMIYAH" DALAM HiduP dan Kehidupan di PondoK Modern Darussalam Gontor.}

Yang dimaksud dengan "Ukhuwah Islamiyah" sebagai jiwa Pondok Modern Darussalam Gontor yang akan memelihara kelangsungan hidup pesantren dan menentukan filsafat hidup para santrinya yaitu sebagaimana yang dirumuskan oleh KH.Imam Zarkasy bahwa yang dimaksud dengan jiwa ukhuwah islamiyah adalah:

Jiwa ukhuwah Islamiyah adalah bahwa kehidupan di pondok pesantren harus diliputi oleh suasana dan perasaan persaudaraan yang akrab sehingga segala kesenangan dan kesusahan dapat dirasakan bersama dengan jalinan perasaan keagamaan. Persaudaraan ini bukan hanya selama berada dipondok pesantren tetapi juga harus mempengaruhi arah persaudaraan dan persatuan umat yang luas. ${ }^{36}$

Apa yang telah dirumuskan oleh Pimpinan Pondok Modern Darussalam Gontor tentang konsep-konsep "Jiwa

${ }^{35}$ Lihat dalam Booklet Pondok Modern Gontor Ponorogo Indonesia, yang ditulis oleh KH. Abdullah Syukri Zarkasyi, KH. Hasan Abdullah Sahal, dan KH. Imam Badri pada Tahun 2000

${ }^{36} \mathrm{Ibid}$.
Ukhuwah Islamiyah" tersebut selalu diaktualisasikan dalam semua aktifitas di Pondok Modern Darussalam Gontor, sebagaimana hasil observasi peneliti bahwa nilai-nilai ukhuwah islamiyah dan persaudaraan tersebut ditanamkan pada diri santri semenjak mereka masuk di pondok modern Gontor. Bagaimana santri yang jaga rayon mengambilkan nasi bagi kawannya yang sakit, mengantarkannya ke Balai Kesehatan adalah cerminan dari nilai tersebut. Cerminan dari kehidupan sehari-hari mereka di kamar, satu kamar berisi 2530 santri dan mereka berasal dari berbagai daerah yang beragam suku dan bahasa mereka, menunjukkan sebuah ajaran dan nilai persaudaraan yang ditanamkan oleh pondok. Saudara senasib sepenanggungan, saudara seiman dan seagama. Saudara yang bagaimana mereka merapatkan barisan, saling mengucapkan salam dan bersalaman, saling membantu apabila ada yang membutuhkan bantuan, adalah merupakan cermin nilai-nilai ukhuwah islamiyah. ${ }^{37}$

Disamping itu aktualisasi konsep jiwa ukhuwah islamiyah, juga seringnya adanya kunjungan dqan shilatur rahim dari pejabat, tokoh-tokoh pendidikan, politik, sosial, ekonomi dan lain sebagainya baik tingkat nasional maupun internasional, yang itu semua adalah cermin dari jiwa ukhuwah islamiyah Pondok Modern Gontor yang selalu menciptakan suasana dan perasaan persaudaraan yang akrab sehingga segala kesenangan dan kesusahan dapat dirasakan bersama dengan jalinan perasaan keagamaan.

${ }^{37}$ Hasil observasi peneliti di lokasi penelitian tanggal 7 April 2004 
Persaudaraan ini bukan hanya selama berada dipondok pesantren tetapi juga harus mempengaruhi arah persaudaraan dan persatuan umat yang luas. ${ }^{38}$

\section{Aktualisasi Nilai-nilai "JiWa Kebebasan" dalaM HiduP daN Kehidupan di PondoK Modern Darussalam Gontor.}

Yang dimaksud dengan "Jiwa Kebebasan" sebagai jiwa Pondok Modern Darussalam Gontor yang akan memelihara kelangsungan hidup pesantren dan menentukan filsafat hidup para santrinya yaitu sebagaimana yang dirumuskan oleh KH.Imam Zarkasy bahwa yang dimaksud dengan jiwa kebebasan adalah:

Bebas dalam berfikir dan berbuat, bebas dalam menentukan masa depannya, dalam memilih jalan hidup didalam dengan berjiwa besar dan optimis dalam menghadapi kehidupan. Hanya saja dalam suasana kebebasan ini sering kali kita temui unsurunsur negatif, yaitu apabila kebebasan itu disalahgunakan, sehingga terlalu bebas (untuk tidak mau dipengaruhi), berpegang teguh kepada tradisi yang dianggap sendiri telah (pernah) menguntungkan pada zamannya, sehingga tidak hendak menoleh keadaan sekitarnya. Akhirnya tidak bebas lagi, karena mengikatkan diri kepada yang diketahui itu saja. Maka kebebasan ini harus dikembalikan kepada aslinya, yaitu bebas dari garis-garis

\footnotetext{
${ }^{38}$ Lihat dalam Booklet Pondok Modern Gontor Ponorogo Indonesia, yang ditulis oleh KH. Abdullah Syukri Zarkasyi, KH. Hasan Abdullah Sahal, dan KH. Imam Badri pada Tahun 2000.
}

DISIPLIN YANG POSITIF dengan penuh tanggungjawab, baik dalam kehidupan pondok pesantren itu sendiri maupun dalam kehidupan masyarakat. ${ }^{39}$

Apa yang telah dirumuskan oleh Pimpinan Pondok Modern Darussalam Gontor tentang konsep-konsep "Jiwa Kebebasan" tersebut selalu diaktualisasikan dalam semua aktifitas di Pondok Modern Darussalam Gontor, sebagaimana hasil observasi dan dokuemenasi peneliti bahwa tiap-tiap santri diberi kebebasan untuk menentukan jenis kegiatan dan aktifitas pada saat-saat mereka tidak dalam suatu kegiatan rutin. Mereka juga diberi kebebasan untuk berpikir, mengemukakan pendapat. Dalam berpidato misalnya, mereka bebas memilih judul apapun yang disukai tanpa ada sesuatu yang membatasi ruang-gerak mereka. Bebas tetapi bertanggungjawab. Bertanggungjawab dalam pengertian mereka memahami konsekuensi moral dan sosial yang harus ditanggung atas perbuatannya. Dalam berpakaian misalnya, di pondok tidak ada seragam, kecuali baju pramuka yang itupun hanya dipakai sekali dalam satu minggu. Para santri diberikan keleluasaan untuk memilih dan memakai baju dan pakaian sesuai dengan selera mereka. Semua baju boleh kecuali baju yang berbau politik, dan kedaerahan. ${ }^{40}$

\section{Temuan Penelitian}

Berangkat dari paparan data diatas, ada tiga temuan hasil penelitian terkait fokus penelitian "aktualisasi nilai-nilai tasawuf dalam hidup dan kehidupan di

\footnotetext{
${ }^{39}$ Ibid.

${ }^{40}$ Hasil observasi peneliti di lokasi penelitian tanggal 9 Mei 2004.
} 
Pondok Modern Darussalam Gontor". Tiga temuan tersebut adalah yaitu: (1) telah terjadi pengejewantahan nilai-nilai tasawuf dalam hidup dan kehidupan di Pondok Modern Darussalam Gontor; (2) Disiplin merupakan Sarana dan Proses Aktualisasi Tasawuf Akhlaqi; (3) Panca Jiwa Pondok Modern Darussalam Gontor merupakan tiang penyangga pondok modern Gontor dalam pembinaan SDM era pendidikan global dan hedonisme kultural.

\section{Pengejewantahan Nilai-nilai TASAWUF DALAM HIDUP DAN Kehidupan di PondoK Modern GONTOR}

Telah terjadi pengejewantahan nilainilai ihsan (esensi Tasawuf) dalam proses pendidikan dan pengajaran di Pondok Modern Darussalam Gontor yang dijadikan sebagai ruh/jiwa yang akan memelihara kelangsungan hidup Pondok Modern Darussalam Gontor. Hal tersebut tersirat dalam pernyataan KH.Imam Zarkasy bahwa "hal yang paling penting dalam pesantren bukanlah pelajarannya semata-mata, melainkan juga jiwanya. Jiwa itulah yang akan memelihara kelangsungan hidup pesantren dan menentukan filsafat hidup para santrinya". Pernyataan tersebut menunjukkan bahwa yang menjadi tiang penyangga atau ruh/jiwa berdirnya pondok pesantren Moden Gontor adalah nilainilai terpuji yang merupakan pengejawantahan nilai-nilai ihsan (esensi tasawuf). Nilai-nilai ihsan tersebut dikukuhkan yang kemudian disebut dengan "Panca Jiwa". Dengan demikian mengingat esensi tasawuf adalah pada pengejawantahan ihsan (Jiwa keikhlasan, Jiwa kesederhanaan, Jiwa kesanggupan menolong diri sendiri atau berdikari, Jiwa ukhuwah Islamiyah dan Jiwa yang bebas), dan sementara itu esensi Pondok Modern Darussalam Gontor terletak pada pembinaan kepribadian santri yang bermanfaat bagi umat (muhsin). Maka secara substansial tasawuf telah menjadi tiang penyangga berdirnya pondok Modern Darussalam Gontor atau tasawuf sebagai subkultur pondok Modern Darussalam Gontor.

\section{Disiplin MERUPakan SARANa daN Proses Aktualisasi Tasawuf AKHlaQI.}

Aktualisasi dan pemberdayaan nilainilai Panca Jiwa tersebut dalam kehidupan sehari-hari santri di Pondok Modern Darussalam Gontor, adalah merupakan perwujudan dari ihsan, yang berarti kesadaran adanya konskuensi seorang hamba untuk mendekatkan diri kepada Allah dengan melaksanakan semua perbuatan-perbuatan yang terpuji dan menjauhi semua perbuatan yang dilarangNya. Konsep inilah dalam tasawuf dinamakan dengan Tasawuf akhlaqi. Hal ini bisa dilaksanakan, apabila seorang individu selalu mensucikan jiwanya yang diformulasikan pada pengaturan sikap mental dan pendisiplinan tingkah laku yang ketat, guna mencapai kebahagiaan yang optimal, yang bermula dari pembentukan pribadi yang bermoral paripurna dan berakhlak mulia yang dalam ilmu tasawuf dikenal dengan takhalli (pengosongan diri dari sifat-sifat tercela), kemudian tahalli (menghiasi diri dengan sifat-sifat terpuji), dan yang terakhir adalah tajalli (terungkapnya nur ghaib bagi hati yang telah bersih sehingga mampu menangkap cahaya ketuhanan) ${ }^{41}$

${ }^{41}$ H.M. Amin Syukur \& H. Masyaruddin, Intelektualisme Tasawuf al-Ghazali (Yogyakarta: Pustaka Pelajar, 2002), 45 
Aktivitas harian di Pondok Modern Gontro tidak terlepas dari Panca Jiwa Pondok Modern Gontor. Beberapa kegiatan tersebut adalah sebagai aktualisasi nilai-nilai yang tersirat dalam Panca Jiwa, yaitu: (1) Shalat malam dan membaca Al-Qur'an yang dilaksanakan dengan secara khusyu' degan penuh kesadaran adalah cermin nilai-nilai keikhlasan sebagimana yang tersirat dalam Panca Jiwa; (2) Pakaian rapi dan sejenis, tidak ada yang memakai pakaian yang "nyleneh", seperti baju kotak-kota, batik, jin dst, adalah cermin kesederhaan. Baik dari keturunan orang kaya dan orang yang miskin, semunya dilatih dengan pola hidup sedernaha. Ini adalah cermin dari jiwa kesederhaan; (3) Aktifitas ritual ibadah sholat yang selalu dilaksanakan berjamaah adalah cermin dari jiwa ukhuwah islamiyah yang selalu menjadi jiwa hidup pesantren, (4) ketepatan waktu dalam melaksanakan setiap aktifitas adalah juga merupakan muraqabah dan cermin dari jiwa disiplin positif sebagaimana yang dimaksud dalam jiwa kebebasan yakni bebas dari garis-garis DISIPLIN YANG POSITIF dengan penuh tanggungjawab, baik dalam kehidupan pondok pesantren itu sendiri maupun dalam kehidupan masyarakat; (5) kegiatan santri belajar, kebersihan lingkungan sendiri, mempersiapkan sekolah sendiri dan lain sebagainya adalah cermin dari nilai-nilai yang tersirat dalam jiwa berdikari, yang mana santri harus belajar dan berlatih mengurus segala kepentingannya sendiri. Itu semua adalah merupakan proses pendidikan dan pelatihan agar santri terbiasa dengan sifat-sifat terpuji dan tidak ada kesempatan sedikitpun untuk melaksanakan perbuatan atau sifat-sifat tercela.
Dan tujuan akhir dari itu semua adalah agar tumbuhnya kesadaran adanya konskuensi setiap santri untuk mendekatkan diri kepada Allah dengan melaksanakan semua perbuatanperbuatan yang terpuji dan menjauhi semua perbuatan yang dilarangNya. Konsep inilah dalam tasawuf dinamakan dengan Tasawuf akhlaqi. Dengan demikian dapat disimpulkan bahwa aktualisasi dan pemberdayaan nilai-nilai Pancajiwa dalam hidup dan kehidupan di Pondok Modern Darussalam Gontor, merupakan perwujudan dari esensi tasawuf akhlaqi yang berarti bahwa adanya kesadaran konskuensi untuk mendekatkan diri kepada Allah dengan melaksanakan semua perbuatan-perbuatan yang terpuji dan menjauhi semua perbuatan yang dilarangNya.

Panca Jiwa Pondok Modern Darussalam Gontor merupakan tiang penyangga pondok modern Gontor dalam pembinaan SDM era pendidikan global dan hedonisme kultural.

Setiap pesantren niscaya mendambakan dan ikut serta berupaya melahirkan generasi penerus (out put) atau santri yang selain memiliki keunggulan bersaing (competitive advantage) untuk menjadi subyek dalam percaturan di dunia kerja juga memiliki kepribadian yang utuh (integrated personality) sehingga dapat memakmurkan dan memuliakan kehidupan material dan spiritual diri, keluarga dan masyarakatnya berdasarkan nilai-nilai Islam. ${ }^{42}$

\footnotetext{
42 Demikian makna eksplisit al-Qur'an, surat alNisaa' ayat 9 yang artinya "Dan hendaklah takut orang-orang yang seandainya meninggalkan di belakang mereka anak-anak yang lemah, yang mereka khawatir terhadap (kesejahteraan) mereka. Oleh sebab itu hendaklah mereka bertaqwa kepada Allah SWT dan mengucapkan perkataan yang benar."
} 
Dalam rangka untuk mencapai dambaan tersebut diatas,, pada saat abad ke-21 sekarang ini lembaga pendidikan dihadapkan pada tantangan arus era globalisasi yang mempengaruhi perkembangan sosial budaya masyarakat muslim Indonesia umumnya atau pendidikan Islam, termasuk Pesantren, Meskipun globalisasi menciptakan kecenderungan untuk peningkatan kerjasama internasional dan regional yang berusaha mewujudkan kemakmuran ekonomi dan kemajuan ilmu pengetahuan dan teknologi, serta perubahan ekonomi masyarakat makin cerdas, profesional dan trampil mengolah alam dan lingkungan hidup bagi kebutuhan hidupnya, namun tanpa disadari telah muncul pula penurunan kualitas kepribadian manusia. Disamping itu pesantren dihadapkan pada tantangan arus pendidikan global yang berideologi kapitalisme sekuler dan kondisi masyarakat yang sudah menjadi rimba hedonisme, sebab pada ke-21 sebagaimana disebut banyak orang adalah millinimum baru yang kita belum tahu persis bagaimana sosoknya, akan dibawa kemana umat manusia. Dan sekarang ini dunia telah berada dalam kesepakatan bahwa abad ke-21 ini diselimuti oleh alam perdagangan bebas dan globalisasi, dimana kompetisi antara individu, antara negara dan antar usaha akan semakin tajam. Dunia secara global pada abad 21 ini, telah memihak pada kepentingan pasar. Pada tahun 2003 yang lalu kita sudah memasuki era perdagangan bebas ASEAN, yang secara formal telah diratifikasi dalam AFTA pada tahun 2010. Dan tahun 2020 memasuki era perdagangan bebas dalam konteks kerjasama Asia dan fasifik (APEC). Maka millinium ketiga, kita berada dalam arus besar kehidupan yang berparadigma kapitalisme dan kondisi masyarakat yang akan menjadi rimba hedonisme (pengultusan kesenangan duniawi).

Dalam rengka menghadapi fenomena sebagai tersebut diatas, Pondok Modern Darussalam Gontor bisa dijadikan rujukan pesantren lain dalam menghadapi tatangan arus globalisasi dan tantangan arus pendidikan global yang berideologi kapitalisme sekuler dan kondisi masyarakat yang sudah menjadi rimba hedonisme. Analisis ini didasarkan pada:

Pertama, Pondok Modern Darussalam Gontor sebagai lembaga pendidikan Islam, telah mampu mengahadapi tantangan globalisasi sebagaimana tersebut diatas, sebab dalam proses pendidikannya (mempersiapkan out putnya), pendekatan yang digunakan adalah berpijak pada "pendekatan religik-filosofis", sebagaimana tersirat dalam Panca Jiwa yang dijadikan sebagai dijadikan sebagai ruh/jiwa yang akan memelihara kelangsungan hidup pesantren Modern Darussalam Gontor. Dengan pendekatan tersebut, sistem pendidikan Islam harus berorientasi pada keseimbangan antara kepentingan duniawi (the worldly oriented) dan ukhrawi. Selain itu pendidikan Islam juga bukan sekedar pendidikan budaya (cultural education), dan juga bukan sekedar pendidikan yang semata-mata bertolak dari/dan berorientasi pada upaya pengembangan dan pelestarian sosio-kultural tertentu, tetapi sekaligus dan bahkan yang lebih utama bermaksud menanamkan pengetahuan yang berguna ('ilm nafi') dalam rangka merealisasikan fitrah manusia sebagai 
hamba Alloh dan khalifatullah, ${ }^{43}$ yang dapat mendekatkan manusia dengan khaliq-Nya (al-'ilm al-nafi' huwa alladzi yutsmiru khasyata Allah ta'ala).

Kedua, Pondok Modern Gontor, telah mencerminkan keberhasilan baik dalam konteks kualitas proses dan mutu hasil pendidikan maupun kualitas keberagamnya di dalam dan luar negeri. Keberhasilan Pondok Modern Gontor tersebut tidak lepas landasan filosofi yang tersirat dalam panca jiwa serta gigihnya para pemimpin Pondok Modern Darussalam Gontor dalam mengaktualisasi dan membemberdayaan nilai-nilai panca jiwa dalam hidup dan kehidupan di Pondok Modern Darussalam Gontor.

Ketiga, Pondok Modern Darussalam Gontor telah memliliki tiga kekuatan secara seimbang yang dapat menghantarkan Pondok Modern Darussalam Gontor berhasil dalam (1) menjadikan Pondok Modern Gontor yang niscaya selalu melahirkan generasi penerus (out put) yang memiliki kepribadian yang utuh (integrated personality) sehingga dapat memakmurkan dan memuliakan kehidupan material dan spiritual diri, keluarga dan masyarakatnya berdasarkan nilai-nilai Islam; (2) menjadikan Pondok Modern Gontor memiliki keunggulan bersaing (competitive advantage) untuk menjadi subyek dalam percaturan dunia global abad 21 yang telah memihak pada kepentingan pasar, yang berada pada

${ }^{43}$ Husein, Syed Sajjad, \& Al-Asyraf, Syed Ali, Crisis in Muslim Education, Hodder and Stoughton : King Abdul Aziz University, Jeddah, (diterjemahkan oleh Mudhafir, Fadhlan 2000. Krisis dalam Pendidikan Islam, Jakarta : Al-Mawardi Prima Anggota IKAPI, hlm. ix). arus besar kehidupan kapitalisme dan kondisi masyarakat yang sudah menjadi rimba hedonisme. Tiga kekeutan tersebut adalah kekuatan dalam bidang SDM, kekuatan dalam bidang manajemen dan kekuatan dalam bidang dana.

Kekuatan pertama, kekuatan dalam bidang sumber daya manusia. Kekuatan dalam bidang sumber daya manusia mulai dari tenaga pendidik (guru) yang unggul, pengelolaan yang profesional dan tenaga peneliti dan pengembangannya yang andal, sangat tercermin dalam pola hidup dan kehidupan Pondok Modern Darussalam Gontor, Hal ini terbukti SDM Pondok Modern Darussalam Gontor yang penuh melaksanakan aktifitas pendidikan dan pengajaran dengan dengan jiwa keikhlasan, yaitu "Sepi ing pamrih (tidak didorong oleh keinginan memperoleh keuntungan-keuntungan tertentu), tetapi semata-mata karena ibadah, karena Allah. Hal ini meliputi segenap suasana kehidupan di pondok pesantren. Kyai ikhlas dalam mengajar, para santri ikhlas dalam belajar, lurah pondok ikhlas dalam membantu (asistensi). Segala gerak-gerik dalam pondok pesantren berjalan dengan suasana keikhlasan yang mendalam. dengan demikian terdapatlah suasana hidup yang harmonis, antara kyai yang disegani dan santri yang taat dan penuh cinta serta hormat". Apa yang telah dirumuskan oleh Pimpinan Pondok Modern Darussalam Gontor tersebut tentang konsep-konsep "jiwa keikhlasan" selalu diaktualisasikan dalam semua aktifitas, baik aktifitas harian, mingguan, maupun bulanan sebagaimana telah dipaparkan pada paparan data yang kesemuanya dilakukan semata-mata karena amanat 
yang diberikan kepadanya oleh pimpinan pondok yang tentunya pertanggungjawabannya tidak sematamata kepada pimpinan akan tetapi kepada Allah serta karena tanggung jawab dan sadar akan arti sebuah pengabdian.

Kekuatan kedua, kekuatan dalam bidang manajeman. Kekuatan dalam bidang manajeman dan kinerja yang didukung oleh peralatan teknologi canggih sehingga akan dapat mendukung efisiensi dan akselerasi. Demi kepentingan pendidikan dan pengajaran Islam, Imam zarkasy selaku pendiri Pondok Modern Darussalam Gontor telah mewakafkan Pondok Modern Gontor kepada sebuah lembaga yang disebut Badan Wakaf Pondok Modern Gontor. Ikrar pewakafan ini telah dinyatakan di muka umum oleh ketiga pendiri Pondok tersebut. Dengan ditandatanganinya Piagam Penyerahan Wakaf itu, maka Pondok Modern Gontor tidak lagi milika pribadi atau perorangan sebagaimana dijumpai dalam lembaga pendidikan pondok pesantrren tradisional. Dengan demikian Pondok Modern Gontor menjadi milik umat Islam, dan umat Islam beratanggungjawab atasnya. Lembaga Badan Wakaf ini selanjutnya menjadi badan tertinggi di pondok Modern Gontor. Badan inilah yang bertanggungjawab mengangkat Kyai untuk masa jabatan lima tahun. Dengan demikian kyai bertindak sebagai mandataris dan bertanggung jawab kepada badan wakaf. Untuk itu Badan Wakaf memiliki lima program, yakni yang berkenaan dengan (1) pendidikan dan pengajaran, (2) bidang peralatan dan peregedungan, (3) bidang perwakafan dan sumber dana, (4) bidang kaderisasi, (5) bidang kesejahteraan. Dengan struktur kepengurusan yang demikian, maka kyai dan keluarga tidak punya hak material apapun dari Gontor. Kyai dan guru-guru tidak mengurusi uang daria santri, sehingga mereka tidak pernah membedakan antara santri yang kaya dan yang kurang mampu. Urusan keuangan menjadi tanggungjawab petugas kantor tata usaha yang terdiri dari beberapa orang santri senior dan guru yang secara periodic bisa diganti. Dengan demikian pengatuaran jalannya organisasi pendidikan menjadi dinamis, terbuka dan obyektif.

Kekuatan ketiga, kekuatan dalam bidang dana. Pondok Modern Darussalam Gontor mempunyai kekuatan dalam bidang dana yang bersumber dari kekuatan lembaga itu sendiri. Kekuatan inilah yang menjadikan Pondok Modern Darussalam Gontor mampu menghadapi hedonisme kultural. Inilah salah satu cermin "Jiwa Berdikari" sebagai jiwa Pondok Modern Darussalam Gontor. Dengan jiwa berdikari (self help) atau berdikari; pondok modern Gontor sebagai lembaga pendidikan tidak menyandarkan kehidupannya kepada bantuan dan belas kasihan orang lain, tetapi kekuatan tersebut dibangun dari kekuatan lembaga sendiri dengan membangun kekuatan ekonomik seperti dengan mendirikan KUK (Koperasi Unit Keluarga) La Tansa yang ada di beberapa kota besar di Indoensia, pabrik roti, percetakan, peternakan, pertanian, toko buku, perkebunan dan usaha-usaha kecil lainnya, itu semua adalah adalah wujud dari jiwa kemandirian pesantren yang mampu mejadikan Pondok Modern Gontor menghadapi arus besar pendidikan global dan hedonisme kultural. 


\section{Penutup}

Dari pembahasan diatas, dapat disimpulkan bahwa (1) Tasawuf sebagai subkultur Pondok Modern Gontor. Hal ini terbukti bahwa esensi tasawuf di Pondok Modern Darussalam Gontor terletak pada pengejawantahan nilainilai terpuji dalam pembinaan kepribadian individu santri yang dikukuhkan sebagai ruh/jiwa pesantren yang akan memelihara kelangsungan hidup pesantren dan menentukan filsafat hidup para santrinya. Jiwa itulah yang disebut dengan istilah PANCAJIWA, yaitu jiwa keikhlasan, jiwa kesederhanaan, jiwa berdikari, jiwa ukhuwah islamiyah dan jiwa bebas; (2) Aktualisasi dan pemberdayaan nilainilai Pancajiwa dalam hidup dan kehidupan di Pondok Modern Darussalam Gontor, merupakan perwujudan dari esensi tasawuf akhlaqi yang berarti bahwa adanya kesadaran konskuensi untuk mendekatkan diri kepada Allah dengan melaksanakan semua perbuatan-perbuatan yang terpuji dan menjauhi semua perbuatan yang dilarangNya; (3) Proses dan hasil dari aktualisasi/pemb'erdayaan nilainilai yang tersirat dalam Pancajiwa Pondok Modern Gontor telah berhasil (a) menjadikan Pondok Modern Gontor yang niscaya selalu melahirkan generasi penerus (out put) yang memiliki kepribadian yang utuh (integrated personality) sehingga dapat memakmurkan dan memuliakan kehidupan material dan spiritual diri, keluarga dan masyarakatnya berdasarkan nilai-nilai Islam; (b) menjadikan Pondok Modern Gontor memiliki keunggulan bersaing (competitive advantage) untuk menjadi subyek dalam percaturan dunia global abad 21 yang telah memihak pada kepentingan pasar, yang berada pada arus besar kehidupan kapitalisme dan kondisi masyarakat yang sudah menjadi rimba hedonisme. 
Ali, A. Mukti, Ta'lim Al-Muta'allim Cermin Imam Zarkasy. Gontor: Trimurti, 1991

Arifin, H. Muzayyin, Ilmu Pendidikan Islam. Jakarta: Bumi Aksara, 1994

Azra, Azyumardi, Pendidikan Islam: Tradisi dan Modernisasi Menuju Millinium Baru. Jakarta: Penerbit Kalimah, 2001.

Bogdan dan Biklen, Qualitative Research for Education, An introduction to theory and methods. Boston: Allyn and Bacon, 1982,

Bruinessen, Martin Van, Tarekat Naqsabandiyah di Indonesia: Survei Historis, Geografis dan Soisologis. Bandung: Mizan, 1992

Dhafir, Zamarkasy, Tradisi Pesantren, Studi tentang Pandangan Hidup Kyai. Jakarta: LP3ES,1985

Dosen Filsafat Ilmu Fakultas Filsafat UGM, Filsafat Ilmu. Yogyakarta: Liberty, 2001.

al-Ghazali, Abu Hamid al-Ghazali, Ihya' Ulumuddin. Kairo: Dar-al-Maarif, 1939

Husein, Syed Sajjad, \& Al-Asyraf, Syed Ali, Crisis in Muslim Education, Hodder and Stoughton: King Abdul Aziz University, Jeddah, diterjemahkan oleh Mudhafir, Fadhlan 2000. Krisis dalam Pendidikan Islam. Jakarta: AlMawardi Prima Anggota IKAPI.

Hussein, Hussein \& Syed Ali Al-Asyraf, Crisis in Muslim Education, (Hodder and Stoughton : King Abdul Aziz
University, Jeddah, diterjemahkan oleh Fadhlan Mudhafir, Krisis dalam Pendidikan Islam, (Jakarta: Al-Mawardi Prima Anggota IKAPI, 2000), hlm. ix.

al-Kalabadi, Abu bakar Muhammad alKalabadi, buku "al-ta'aruf li al madzhab al-tashawuf. Kairo:1960

Lincoln dan Guba, Naturalistic Inquiry. Bevery Hills: SAGE Publications

Lonfland, Analyzing Social Setting, A Guide to Qualitative Observation and Analysis, Belmont, Cal: Wadsworth Publishing Company, 1984

Madjid, Nurcholis, Bilik-bilik Pesantren; Sebuah Potret Perjalanan. Jakarta: Paramadina, 1997

Marriam, S.B., G Simpson, E.L., A.Quide to research for Educators and trainer on adults. Malabar, Florida: Robert E. Krieger Publishing Company, 1984.

Masthu, Dinamika Sistem Pendidikan Pesantren. Jakarta : INIS, 1994.

Miles dan Hubermen, Qualitative Data Analysis, A. Sourcebook of New Methods, Beverly Hills, Sage Publications, 1984.

Moleong, Lexy, Metodologi Penelitian Kualitatif. Bandung: PT Remaja Rosda Karya, 2000

Najib, Emha Ainun, Slilit Sang Kyai. Jakarta Grafiti, 1992

Nasution, Harun, Filsafat dan Mistisisme dalam Islam. Jakarta: Bulan Bintang, 1995 
Nasution, Harun, K.H. Imam Zarkasyi dalam Ensiklopedi Islam di Indonesia, Jakarta: Departemen Agama, 1988.

Ni'am, Nidhaman, Tasawuf dan Krisis. Yokyakarta: Pustaka Pelajar: Anggota IKAPI, 2001

Patton, Qualitative Evaluation Methods, Beverly Hills, Sage Publications, 1980

Saifullah, Ali, Darussalam, Pondok Pesantren Modern Gontor, Pesantren dan Pembaharuan. Jakarta: LP3ES, 1985

Simuh, dkk, Tasawuf dan Krisis. Yogyakarta: Pustaka Pelajar, Anggota IKAPI, 2001.

Spradley, J.P. Participant Observation. New York: Holt, Rinehart and Winston, 1980.

Syukur, HM. Amin, Zuhud di Abad Modern. Yokyakarta: Pustaka Pelajar: Anggota IKAPI, cet ke-2, 2000.

Thouless, Robert H., Pengantar Psikologi Agama (Jakarta: Rajawali Press, 1995
Wardun, Warta Dunia Pondok Modern, Risalah Akhir Tahun Ajaran 14001401 H/1980-1981. Gontor: 2003

Yunus, Mahmud, Sejarah Pendidikan Islam di Indobesia. Jakarta: Mutiara, 1979

Zahri, Mustafa, Kunci Memahami Ilmu Tasawuf. Surabaya: Bina Ilmu, 1979

Zarkasy, H. Amal Fathullah, Pondok Pesantren sebagai Lembaga Pendidikan dan Dakwah. Jakarta: Gema Insani Press, 1998.

Zarkasy, KH. Wasiat, Pesan, Nasehat dan Harapan Pendiri Pondok Modern Gontor . Gontor, tt

Zarkasyi, KH. Abdullah, KH. Hasan Abdullah Sahal, dan KH. Imam Badri, Booklet Pondok Modern Gontor Ponorogo Indonesia. Gontor: 2000.

Ziemek, manfred, Pesantren Dalam Perubahan Sosial. Jakarta: LP3M, 1986 